\author{
(online) $=$ ISSN $2285-3642$ \\ ISSN-L = 2285 - 3642 \\ Journal of Economic Development, Environment and People \\ Volume 4, Issue 4, 2015 \\ URL: $\underline{\text { http://jedep.spiruharet.ro }}$ \\ e-mail: office jedep@spiruharet.ro
}

\title{
Arbitral Tribunal Power to Disqualify Unethical Counsel ${ }^{1}$
}

\author{
Cristina FLORESCU \\ University Spiru Haret, Faculty of Legal, Political and Administrative Science Bucharest, \\ 24 Sos. Berceni, $4^{\text {th }}$ District, Bucharest, 41917, Romania \\ Tel: +40 722236757, Fax: + 4021 3345263, Email: cristina.florescu@spiruharet.ro
}

\begin{abstract}
In specific matters of conflicts of interest ethical issues in connection with the parties' legal representatives could occur in the course of arbitration proceedings. The purpose of this paper is to identify and investigate the current status of the arbitral tribunals and arbitral institutions power to sanction counsel's misconduct in the event of conflicts of interest. Parties have a fundamental right to choose the counsel and in the same time the right to an independent and impartial tribunal, therefore the source of the arbitral tribunal power to disqualify a counsel is a hot topic. There are no express provisions granting arbitrators such power, only soft law instruments, but which have no binding effect as long as the parties do not agree on them. For these reasons, two renowned cases where international arbitral tribunals have dealt with the subject are examined. Developing "truly transnational" ethical rules and their implementation by the arbitral institutions might be a solution. Arbitral tribunals are establishing this issue on the basis of the undertaken and applied international soft law (professional guidelines) which gained credibility and popularity and also became accepted international standards in the arbitration field.
\end{abstract}

Keywords: international arbitration, arbitrator, counsel, party representative, guidelines, conflicts of interest

JEL classification: F53, K19, K22, K29, K33, K41, K49

\section{Introduction}

International commercial arbitration is developing rapidly and becomes one of the fastest alternative to litigation means of dispute resolution concerning business world without replacing litigation and ensuring an especial administration of justice.

The ethical quality of the arbitration depends and it is determined by the ethical quality of its arbitrators and also by the major participants on the arbitral proceedings. This being said, besides the arbitrators called to ensure the due process, effectiveness, efficiency and also to preserve and protect the arbitral process, the party representatives/ counsels are actors with significant role and functions to deter all the guerrilla tactics imported nowadays in arbitration from litigation [Rogers, 2014; Horvath \& Wilske, 2013].

\footnotetext{
${ }^{1}$ The article was previous presented at International Conference on Economic Sciences and Business Administration 2015
} 


\author{
(online) $=$ ISSN $2285-3642$ \\ ISSN-L = 2285- 3642 \\ Journal of Economic Development, Environment and People \\ Volume 4, Issue 4, 2015 \\ URL: http://jedep.spiruharet.ro \\ e-mail: office jedep@spiruharet.ro
}

As international arbitration becomes more widespread and accepted as not just an alternative dispute resolution but a more appropriate method, there has been a significant growth in the pool of arbitrators and a corresponding broadening of the cultural and legal traditions among them and the parties. In connection with this, law firms and corporations, group of companies and entities became larger and with a more complex and different structure, advancing new and more perceptive issues on conflict of interest and its meaning. This growth, increased complexity and diversification nurtured new and more challenges to the former agreement among arbitrators and parties about what is right with regard to arbitrator conduct [Rogers \& Jeng, 2014, p. 175]. In the same time, there have been developments in the international arbitration practice, which tends to transparency and a more formalistic approach, which triggered more arbitrators' challenges and this conducted to a more need for standardization and codification on conflicts of interest issues.

Within the historical context of the development of international relations, the last years witnessed a record evolution of the ethical issues in international arbitration. During the last 20 years a lot of international law codification was realized and it contributed to the growth of the regulatory effect of international arbitration in new fields of business, economic, social, cultural and even political. As a result of the development and challenges in business reality, the international arbitration needs to be prepared for the increase in disputes and high-profile disputes that implies a multitude of participants (arbitrators, arbitral institutions, parties, their legal and contractual representatives, counsels, experts, witnesses etc.) and the ethical issues that arose between them. A participant to the arbitration proceedings may be an arbitrator in one case and counsel, expert or witness in another. Alleged conflicts of interest can arise from some actors alternating between different functions. This situation may lead to the possibility of several conflicts of interest among these actors, when prospective appointments and necessary disclosure is concerned, considering that sometimes a counsel may become an arbitrator, an expert or an witness or vice-versa and all these qualities may interchange in the light of the ever-growing importance of arbitration as means of dispute resolution and its pool of participants to the arbitral proceedings.

Thus, it is not unexpected that arbitrators and counsels' ethics have become the focus of more and more exhaustive and comprehensive rules and codes, which have been enhanced and developed by arbitral rules, the procedures for selection and challenge of arbitrators and other arbitration players, the standards that apply to review of final awards, as well as applicable national criminal laws, such as those prohibit money laundering and corruption [Rogers \& Jeng, 2014, p. 178].

It is true that the arbitrators are those called to implement measures and also keep control and the police of the arbitration process, but responsibility should be borne by other actors in arbitration, such as parties and their representatives (counsels). The discussion here is not of other kind of players in arbitration proceedings, such as witnesses, experts or arbitral institutions. These should be called as well to keep the arbitration on the right track by a correct and ethical behaviour, but the most new rules are on counsels' misconduct and the arbitrators' power to sanction them in cases that amount such actions.

As truly pointed out by Prof. Emmanuel Gaillard in its Freshfield Lecture on 26 November 2014, when he looked at international arbitration he observed its structure to be more likely to a social construct, determined by the interactions of its main actors and their ritualised behaviour, and he opinionated that nowadays the solidaristic model of arbitration moved more to a polarised model. Prof. Gaillard refers also 


\author{
(online) $=$ ISSN $2285-3642$ \\ ISSN-L = 2285-3642 \\ Journal of Economic Development, Environment and People \\ Volume 4, Issue 4, 2015 \\ URL: $\underline{\text { http://jedep.spiruharet.ro }}$ \\ e-mail: office jedep@spiruharet.ro
}

to roles and functions different players could have in arbitration and how these ascertain certain subconscious ideas and conduct of arbitration proceedings that determine the balances to be more incline on one side than the other.

Another prominent scholar and arbitrators, David W. Rivkin, in its Annual Seoul Lecture 2014 on 9 December 2014 entitled Ethics in International Arbitration, mentioned that efficiency and ethics are foremost topics, recently the last one being extensively debated, but without significant success on finding answers. He departed from the observation that "many perceived to be a decline in ethical conduct by counsel in advocating their clients' cases". Certainly, the parties complain more and more about excessive judicialization but their counsels are those which import court alike features in arbitration trying to win at all costs for their clients. It seems unfair that parties and counsels complain about efficiency in time and costs and in the same time they are provoking delays and apply guerrilla tactics. As a consequence, the arbitration community is forced to put more pressure on arbitrators to exercise a more pro-active role and the institutions to issue and apply a stricter and formalistic procedure. Therefore, a much closer look should be paid to the counsels' behaviour and possible misconduct and the need of arbitrators to be vested with more powers to counterbalance this situation.

This paper focus more on the issue of the ethical appointment of a counsel in arbitration proceedings after their commencement in a manner that may disrupt the balance of independence and impartiality of the constituted tribunal due to potential conflicts of interest with the new appointed counsel. And what can be done in such a case, who is called to take sanctions against the counsel, if the arbitrators have or not inherent powers to disqualify/ exclude the counsel in such cases.

\title{
2. On Arbitrators and Counsels' Conflicts of Interest Codification
}

To achieve the goal in international arbitration of "providing a final binding resolution of the parties' dispute" [Born, 2009, International Commercial Arbitration, Austin: Wolters Kluwer, p. 2879, 2880] it is also vital to ensure and respect the ethics of all the participants in the arbitral proceedings. The successful and rapid practice of dispute settlement in various areas determined a major increase of the body of norms and soft law used. Simultaneously with international development some institutional changes also took place and the number of international organizations or institutions with competence in regulation of international arbitration expanded. ("value providers", as Prof. Gaillard named them). The discussion on ethics it seems to have shifted more towards questions of counsel ethics while codes of conduct for arbitrators focus mostly on the questions of impartiality and independence. The arbitrators are compel to their most important obligations of independency, impartiality, neutrality and disclosure in international arbitration. There are some guidelines in this respect issued by international organization which intended to regulate the conflicts of interest issues that may occur mostly when making decisions about prospective appointments and disclosures.

The most prominent and influential professional code of conduct, the American Bar Association/American Arbitration Association's Code of Ethics for Arbitrators in Commercial Disputes (AAA Code of Ethics), originally adopted in 1977 and revised in 2004, "recognizes the fundamental differences between arbitrators and judges". The drafters of the Code believe it is preferable that all arbitrators be 


\author{
(online) $=$ ISSN $2285-3642$ \\ ISSN-L = $2285-3642$ \\ Journal of Economic Development, Environment and People \\ Volume 4, Issue 4, 2015 \\ URL: http://jedep.spiruharet.ro \\ e-mail: office jedep@spiruharet.ro
}

neutral and comply with the same ethical standards (particularly in arbitrations with international aspects). The Code prescribes that all arbitrators should disclose "any known direct or indirect financial or personal interest in the outcome of the arbitration", and "any known existing or past financial, business, professional or personal relationships which might reasonably affect impartiality or lack of independence in the eyes of any of the parties." The Code also prescribes in Canon II(B) that arbitrators have an ongoing duty to "make reasonable efforts to inform themselves of any interests or relationships" subject to disclosure [Brower, 2010].

Other such codifications are Arbitrators Ethics Guidelines provided by JAMS - The Resolution Experts (US), Guidelines of Good Practice and Code of Ethical Conduct of Arbitrators issued by The Chartered Institute of Arbitrators in London (CIArb), which provides also for the CIArb Practice Guideline: Interviewing Prospective Arbitrators., Guidelines for Arbitrators Conducting Complex Arbitrations International Institute for Conflict Prevention \& Resolution (CPR). Nonetheless, the most renowned and used are the International Bar Association codifications, the IBA Guidelines on Conflicts of Interest in International Arbitration (adopted in 2004 and revised in 2014) and IBA Guidelines on Party Representation in International Arbitration (adopted in 2013).

Regarding the IBA Guidelines on Conflicts of Interest, parties and their counsel frequently consider the Guidelines in assessing the impartiality and independence of arbitrators and arbitral institutions and courts often consult the Guidelines in considering challenges to arbitrators. The goal of the IBA Guidelines on Conflicts of Interest stands to help parties, lawyers, arbitrators and arbitration institutions on such relevant issues as impartiality and independence and other ethical arbitration duties including disclosure, communication, diligence and confidentiality. The widespread acceptance of the IBA Guidelines has played a decisive role in bringing global arbitration into line [Fernández Rozas, 2010].

The IBA Guidelines on Party Representation focus on issues of counsel conduct and party representation in international arbitration that are subject to, or informed by, diverse and potentially conflicting rules and norms. They undertook to determine whether such differing norms and practices may undermine the fundamental fairness and integrity of international arbitral proceedings and whether international guidelines on party representation in international arbitration may assist parties, counsel and arbitrators (this is the declaration of the Guidelines themselves in the preamble).

These Guidelines are soft law instruments that provide directions for the regulation of arbitrators' and counsel's conduct, they are not legal norms and do not prevail over the applicable domestic legislations or over the parties' chosen rules of arbitral proceedings. Only their acceptance by the parties to be referred to in the course of their proceedings ensures the application of these standards. Usually the tribunal itself is proposing such reference during the drafting of the main documents in arbitration, such as the Terms of Reference, Procedural Order no. 1 or others.

The IBA Guidelines of 2013 and 2014 are useful steps along the way to a rigorous ethics regime. But with the arbitral institution lies the task to lead the way, their true role being to fill the gaps and support the legitimacy of their arbitration systems. It is difficult for the systems to self-regulate and adapt in due time to the practical issues of irregularities and deviances which are not standardized by the Guidelines, but which permanently transpired from the practice's evolution. Thus the arbitral institutions are more appropriate to provide guidance and authority. The institutions can achieved these by intervening and 


\author{
(online) $=$ ISSN $2285-3642$ \\ ISSN-L = 2285-3642 \\ Journal of Economic Development, Environment and People \\ Volume 4, Issue 4, 2015 \\ URL: $\underline{\text { http://jedep.spiruharet.ro }}$ \\ e-mail: office jedep@spiruharet.ro
}

accomplishing their regulatory role, as they are perceived neutral and can ask for the opinions of the practitioners and all specialists in the field.

These Guidelines are trying to maintain the fragile balance between disclosure of everything and the efficient disclosure of a potential independence and impartiality risk. Those Guidelines cannot be perfect and complete, as they are not able to comprise at a certain moment of their issuance (or adaptation) any possible practical circumstance, but they enlighten over possible situations from which may arise a potential conflict of interest.

Even the arbitrators' duty to disclose is subject to different standards, the general rule is that a prudent arbitrator when is in doubt should disclose that possible conflict, to avoid any risk of penalty, such as removal or setting aside of the award. It has been noted that "non-disclosure plants the seed of nullity" [Hunter \& Paulsson, 1985]. In the view of the IBA Guidelines on Conflicts of Interest non-disclosure cannot lead to consider an arbitrator biased, only the facts or circumstances not disclosed can do so.

The notions of independence, impartiality and neutrality are vague and ambiguous enough, the domestic legislations approaches being different, especially the Europeans requirements being distinct from the US ones. In Europe the independence principle is broadly recognized, while American legislation (Federal Arbitration Act) states that an arbitral award may be annulled (set aside) only if evident and justified reasons of arbitrators' corruption existed.

The different sources of arbitrators and other arbitration players' obligations of independence and impartiality apply at different stages of the proceedings and are applied by different entities for different purposes [Rogers \& Jeng, 2014, p. 178]. These could be ethical codes (such as above mentioned), institutional arbitration rules applied by the respective institution that organize arbitration, national laws, usually applied by national courts and in domestic arbitration if applicable arbitration rules are silent, international conventions, such as Convention on Recognition and Enforcement of Foreign Arbitral Awards (art. $V(1)(d), V(1)(b), V(2)(b)$ - the most common ground being however the violation of the public policy of the enforcement jurisdiction by the alleged arbitrator misconduct). There are also national Bar Associations issuing ethical obligations for lawyers and the invocation of the professional or malpractice liability.

The Romanian Civil Procedure Code entered into force in 2013 ascertains in Article 562 the norms regarding the conflicts of interest, which are imported and inspired from the IBA Guidelines on Conflicts of Interest, in a succinct and concise manner, in order to cover as much as possible from the possible situations described in these Guidelines. They are trying to capture the legal and practical complications which may arise in the contemporary world of international trade and in several other fields where arbitration is utilized, being analysed for this the domestic laws and trade policies from several important jurisdictions. First paragraph of the Article 562 Romanian Civil Procedure Code stipulates that "the arbitrator may be challenged on the following grounds casting doubt upon his or her independence and impartiality:

a) The failure to satisfy the qualifications or other conditions concerning the arbitrators contained in the arbitration agreement;

b) When the arbitrator is an associate of, or serves in the management of, a legal person having an interest in the dispute; 


\author{
(online) $=$ ISSN $2285-3642$ \\ ISSN-L = 2285-3642 \\ Journal of Economic Development, Environment and People \\ Volume 4, Issue 4, 2015 \\ URL: http://jedep.spiruharet.ro \\ e-mail: office jedep@spiruharet.ro
}

c) If the arbitrator is employed in, works for, or has direct commercial relations with one of the parties, or with a company that is controlled by one of the parties or placed under the common control of the parties;

d) If the arbitrator worked as consultant for, assisted or represented one of the parties, or testified in one of the preceding phases of the dispute."

Also, Article 20 of the Arbitration Rules of the Court of International Commercial Arbitration attached to the Chamber of Commerce and Industry of Romania provide for the aarbitrators' incompatibility in the first paragraph in a similar way to the Article 562 cited above: "The arbitrators shall be incompatible for settling a certain dispute for the following reasons, questioning their independence and impartiality:

a) find themselves in one of the situations of incompatibility provided for judges in the Code of Civil Procedure;

b) do not meet the qualifications or other requirements regarding arbitrators provided in the arbitration agreement;

c) a legal person whose associate is the concerning arbitrator or in whose governing bodies the concerning arbitrator is part has an interest in the case;

d) the arbitrator has employment relationships or direct trade links with one of the parties, with a company controlled by one party or that is placed under common control with the same;

e) the arbitrator has provided consultancy to one of the parties, assisted or represented one of the parties or testified in one of the earlier stages of the case."

And in the following paragraph is adding other circumstances related to the counsels' role: "The arbitrator who is also an attorney-at-law, listed on the panel of compatible attorneys-at-law, may not be an arbitrator in a dispute in respect to which he/she carried out or is going to carry out attorney-specific activities; also, he/she may not represent or assist either of the parties in that dispute before the tribunals set up within the Court of Arbitration."

Onward it continues with the third paragraph which specifies that "The attorney-specific activities specified under paragraph 2 may not be performed by the attorney-at-law who is also an arbitrator in a certain dispute, either directly or by replacement by an attorney-at-law within the form of performing the attorney-at-law profession to which that arbitrator belongs."

These national provisions contributed to defining the ethical obligations of arbitrators and their possible or not double hat position when act as counsel in arbitration cases. These stipulations support the clarification of the arbitrator and counsel obligations with regard to the independence and impartiality and the level of proof expected to establish a possible misconduct or a violation.

Regarding the arbitrators' liability, Article 565 Romanian Civil Procedure Code states that "Arbitrators are liable, as prescribed by law, for the damage caused if they:

a) resign, without cause, after accepting the appointment;

b) fail, without cause, to participate in the resolution of the dispute or do not render the award within the term required by the arbitration agreement or the law; 


\author{
(online) $=$ ISSN $2285-3642$ \\ ISSN-L = $2285-3642$ \\ Journal of Economic Development, Environment and People \\ Volume 4, Issue 4, 2015 \\ URL: http://jedep.spiruharet.ro \\ e-mail: office jedep@spiruharet.ro
}

c) do not observe the confidential character of the arbitration, by either publishing or disclosing information acquired in their capacity as arbitrators without the parties' approval; or

d) breach other duties in bad faith or gross negligence."

These provisions strengthen the requirements for a proper conduct and ethical behaviour in good faith of the arbitrators and especially the last duty to act in good faith and without negligence could be applicable as a general obligation to all the arbitration players, hence to counsels as well.

More recently, some arbitral institutions have taken up the challenge of creating codes of conduct for arbitrators acting under their auspices, most of them in Eastern Europe. Examples include the Court of Arbitration at the Polish Chamber of Commerce, the Permanent Court of Arbitration attached to the Chamber of Commerce and Industry of Slovenia or the Latvian Chamber of Commerce and Industry. While some of these codes are no more than general, moral guidelines, others go further and regulate specific situations which typically arise during an arbitration. Sometimes, these rules of ethics are enforced. For example, under the rules of the Permanent Court of Arbitration attached to the Chamber of Commerce and Industry of Slovenia, an arbitrator violating the code of ethics is explicitly considered to have failed to fulfil his or her duties. On the basis of this, the institution "may" terminate the arbitrator's mandate either upon request of a party or, in exceptional circumstances, on its own accord. This regime makes the code of ethics more than just a guideline, creating a mechanism to control an arbitrator's behaviour beyond just the adherence to fundamental principles [Peters, 2010].

It remains to be seen whether arbitral institutions will follow this path of regulating ethics in more depth. For the moment, the major institutions seem inclined to leave this issue to the international arbitral community which have been preoccupied to issue such standards. On an international level, there should be the desire (as the need is already revealed) to aim for an updated extensive and transparent consensus, except, maybe, for the difficulties typically associated with achieving such consensus. The consolidation of an international ethical standard for arbitrators, counsels and other participants in arbitration could be an important step on the way of ensuring the efficiency, integrity and fairness of the arbitral proceedings.

\title{
3. On Counsels and the Topic of Ethics - IBA Guidelines on Party Representation 2013
}

Regarding the counsel's conduct in arbitration, IBA Guidelines on Party Representations are issued to assist parties, counsel, or arbitrators when issues on counsel conduct and party representation in international arbitration as party representatives arise. This conduct may be subject to diverse and hypothetically conflicting bodies of domestic rules.

In the preamble of these Guidelines is expressly stated that the potential for confusion may be aggravated when individual counsel working collectively, either within a firm or through a co-counsel relationship, are they admitted to practice in multiple jurisdictions that have conflicting rules and norms. The general idea promoted by these Guidelines is that party representatives should act with integrity and honesty and should not engage in activities designed to produce unnecessary delay or expense, including tactics aimed at obstructing the arbitration proceedings. 


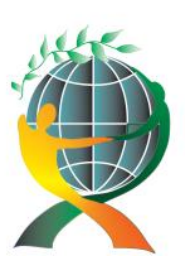

\author{
(online) = ISSN $2285-3642$ \\ ISSN-L = 2285 - 3642 \\ Journal of Economic Development, Environment and People \\ Volume 4, Issue 4, 2015 \\ URL: http://jedep.spiruharet.ro \\ e-mail: office jedep@spiruharet.ro
}

The preamble of the Guidelines strengthen also that as with the International Principles on Conduct for the Legal Profession, adopted by the IBA on 28 May 2011, the Guidelines are not intended to displace otherwise applicable mandatory laws, professional or disciplinary rules, or agreed arbitration rules that may be relevant or applicable to matters of party representation. They are also not intended to vest arbitral tribunals with powers otherwise reserved to bars or other professional bodies. The use of the term guidelines rather than rules is intended to highlight their contractual nature. The parties may thus adopt the Guidelines or a portion thereof by agreement. Arbitral tribunals may also apply the Guidelines in their discretion, subject to any applicable mandatory rules, if they determine that they have the authority to do so. The Guidelines are not intended to limit the flexibility that is inherent in, and a considerable advantage of, international arbitration, and parties and arbitral tribunals may adapt them to the particular circumstances of each arbitration.

The Guidelines take into consideration several aspects related to the counsel's conduct, including communications with arbitrators, submissions to the arbitral tribunal, information exchange and disclosure, witnesses and experts, remedies for misconduct. In Guidelines 4-6 the issue of party representative is treated related to clear identification of the party representatives as soon as possible and if any change occurs, then it should be properly and promptly notified to the other party, the arbitral tribunal and also arbitral institutions (in case of institutional arbitration, which most of them are).

The hottest topic of possible exclusion of a counsel in case of a late appointment which could cause a conflict of interest and derailed the proceedings is tackled and it is stated:

"5. Once the Arbitral Tribunal has been constituted, a person should not accept representation of a Party in the arbitration when a relationship exists between the person and an Arbitrator that would create a conflict of interest, unless none of the Parties objects after proper disclosure.

6. The Arbitral Tribunal may, in case of breach of Guideline 5, take measures appropriate to safeguard the integrity of the proceedings, including the exclusion of the new Party Representative from participating in all or part of the arbitral proceedings."

In the comments dedicated to Guidelines 4-6 it is provided for the hypothesis of this situation: a newlyappointed counsel in the course of the commenced proceedings and a conflict of interest between this nomination and one of the arbitrators of the arbitral tribunal already constituted. In such cases, if the arbitral tribunal finds it has the authority and the circumstances are justified and allow it, then the exclusion of that counsel could be considered under the IBA Guidelines on Conflicts of Interest, partially or totally. Of course, the parties should be invited to express their opinion about the existence of a conflict, the extent of the Tribunal's authority to act in relation to such conflict, and the consequences of the measure that the Tribunal is contemplating [Comments of Guidelines 4-6].

One should not forget that these Guidelines are not norms, but soft law and the participants to the arbitral process should agree on their application and give the arbitral tribunal the power to act in this respect.

In the end the Guidelines is offering a part which articulate potential remedies to address misconduct of party representatives. The measures that could be taken by the arbitral tribunal should be assessed and balanced according to the particular situation analysed, without leaving aside the rights of the parties, relevant considerations of privilege and confidentiality, the good faith of the party representatives and the 


\author{
(online) $=$ ISSN $2285-3642$ \\ ISSN-L = 2285-3642 \\ Journal of Economic Development, Environment and People \\ Volume 4, Issue 4, 2015 \\ URL: $\underline{\text { http://jedep.spiruharet.ro }}$ \\ e-mail: office jedep@spiruharet.ro
}

effects of the measure to be proportionate to the respective misconduct sanctioned. The proposed measures are: admonishing the party representative, drawing appropriate inferences in assessing the evidence relied upon or the legal arguments advanced by the party representative, considering the misconduct in apportioning the costs of the arbitration or any measure that might be considered as appropriate to preserve the integrity and fairness of the proceedings.

Significantly to be remarked is that the proposed sanctions in this final part of the Guidelines makes no specific and express reference to the exclusion of a new counsel having a conflict of interest with one of the arbitrators. This can lead to the conclusion that such a sanction is considered an extreme measure that arbitral tribunal is encouraged to consider only in exceptional cases. As the wording "or any other appropriate measure in order to preserve the fairness and integrity of the proceedings" leaves room for any other sanction, including the counsel disqualification/ exclusion, this means that arbitral tribunal can also adapt and adopt other appropriate measures to the specific circumstances they might came across in an arbitral process, not only a conflict.

\title{
4. Relevant Alternative Measures to Codification
}

If these guidelines are not agreed upon, another solution for counsels who attempt to disrupt the arbitral proceedings is that arbitral institutions to include provisions authorizing a constituted arbitral tribunal to take appropriate measures to prevent and sanction the possible breaches of ethical rules in the exercise of his or her right of defense. These sanctions could be adjusted depending on the severity of the situation at hand: from a written warning and admonishment in minor cases, to the exclusion of the counsel from the arbitration (in whole or in part) in severe cases or cost sanctions. Article 18.6 of the Arbitration Rules of 2014 of the London Court of International Arbitration ("LCIA") consciously shifts in this sense.

Moreover, would be advisable for an arbitral tribunal to reveal these kind of circumstances in the award when it considers the conduct of such a counsel that delayed and damaged the proceedings or caused any harm to the party that appointed the counsel.

In case of counsel repeatedly challenge an arbitrator or the arbitral tribunal, then the arbitral institution should have the power to sanction the counsel rather than the arbitral tribunal, since the tribunal's attempt to sanction counsel in this instance may create the appearance of vengeance [Ziade, 2015, p. 220,221].

\section{On Double Hat Issue in International Arbitration}

Like other professionals living and working in the world, arbitrators as well as counsels or any other participant in arbitration have a variety of complex connections with all sorts of persons and institutions (Vivendi case). An arbitration specialist wrote a much wiser thought that "If arbitrators must be completely sanitized from all possible external influences on their decisions, only the most naïve or incompetent would be available." [Park, 2009].

Besides the guidelines offered by certain organization involved in such codification, codes of conduct and ethics should also be issued by arbitral institutions (as exemplified above) to establish necessary order on the system, especially concerning the relation between different participants in arbitration to preserve 


\author{
(online) $=$ ISSN $2285-3642$ \\ ISSN-L = $2285-3642$ \\ Journal of Economic Development, Environment and People \\ Volume 4, Issue 4, 2015 \\ URL: $\underline{\text { http://jedep.spiruharet.ro }}$ \\ e-mail: office jedep@spiruharet.ro
}

the due process, integrity and efficiency of the arbitral proceedings. In the field of commercial arbitration, the appearance of the same person as counsel in one case and simultaneously as arbitrator in an different case that largely raise similar legal issues could be problematic in some situations.

The practice of allowing arbitrators to serve as counsels and vice-versa raises due process of law issues. Issue conflict or role confusion, seen as special form of pre-judging, can disqualify practitioners who serve simultaneously as counsel and arbitrators, as one quality can be influenced by the other professional commitments [Sands, 2011].

The arbitrators in the capacity of counsel have to choose which duty come first. The counsel attitude of advisor of a party is incompatible with the arbitrator's mission to be unbiased and open to all the merits of the case and also when examine the merits with other fellow arbitrators. Playing both these parts would cause the appearance of not being able to keep them strictly separated, to distance fully from the divergent interests. Usually the arbitrator is invited to choose between the role of an arbitrator or the work as a counsel.

The general idea is the need to maintain a perception of absolute independence of the arbitrator, this being perceived as most vital in the eyes of the arbitration users in order to keep them further to resort to arbitration. Counsels are bound to perceive the broader public perception as to the legitimacy of the international arbitration system as a whole.

Opinions advocating the separation of roles, especially in investment arbitration, contend that arbitrators should not be put into a position where they are tempted, either consciously or subconsciously, to take procedural orders or to draft awards in such a way as to advance their clients' position in a simultaneous case in which they are acting as counsel. The law issues from these two different qualities are in divergence and can create the lack of the due process.

Counterarguments in this respect are that diligent and ethical arbitrators decide their cases on the basis of the facts and law before them and they do not let themselves be manipulated or persuaded by external factors and that considerations are made on the merits of that specific case, not other unduly circumstances.

On the other hand, forcing such a person to choose between its quality of arbitrator or counsel (or others qualities) will deprive the arbitration community of some of its best talents, because usually they opt for the more lucrative role of counsel [Ziade, 2015, p. 218]. Consequently, a more feasible solution would be to let that person to choose its role based on the specific case, the moment of the proceedings and the possible conflicts that may arise, as long as the parties agree upon the proper disclosure of the person in case, to minimize the risk of challenges to arbitrators while enhancing transparency and trust [Ziade, 2015, p. 218, 219].

It is increasingly pointed out that arbitration practitioners wear several hats and that they take the lead in regulating their own activities, while arbitration institutions often refrain from even enacting basic guidelines on conduct [Ziade, 2015, p. 212]. Expanding the pool of arbitrators by the arbitral institutions could establish and ensure a more broad and representative system of the international community. It could also decrease the number of challenges based on repeat appointments of arbitrators and other alleged conflicts of interest, the number of such challenges having escalated manifestly in the last years. 


\author{
(online) $=$ ISSN $2285-3642$ \\ ISSN-L = 2285-3642 \\ Journal of Economic Development, Environment and People \\ Volume 4, Issue 4, 2015 \\ URL: $\underline{\text { http://jedep.spiruharet.ro }}$ \\ e-mail: office jedep@spiruharet.ro
}

It has been observed that most of the independence (better said the lack of independence) issues are due to the increased presence of the multinational entities/groups and the development of size and number of the international law offices as participants to the international arbitration proceedings as factors which influence in a sensitive manner the possible bias of an arbitrator. These aspects could also be extended to counsel participation, especially when such a selection is made later in the proceedings, after the arbitral tribunal is constituted.

\title{
6. Caseload on Disqualifying Counsel
}

The best practices that have been issued and discussed in consideration of the issue whether an arbitral tribunal has the competence to disqualify a counsel is not just so recent [Paulsson, 1992, p. 214, 215], as the problem is if the competence lies with the arbitral tribunal, the arbitral institution administering the case or the state courts. But it obtained recent sensitivity in light of two investment arbitration decisions with different results, Hrvatska [Hrvatska Elektroprivreda, d.d. v. Republic of Slovenia, ICSID Case No. ARB/05/24 - Tribunals' Order concerning the participation of David Mildon QC in further stages of the proceedings, May 6, 2008] and Rompetrol [Rompetrol Group N.V. v. Romania, ICSID Case No. ARB/06/3 Decision of the Tribunal on the participation of a counsel, January 14, 2010].

The International Commercial Arbitration Committee is currently continuing its project on "Inherent Powers of Arbitral Tribunal" (ILA 2014) which was presented at the 2012 Sofia Conference and where a draft report and recommendations were discussed at the ILA2014 Conference in Washington DC with the aim of finalizing the recommendations before the ILA2016 Conference in Johannesburg and final adoption of the recommendations at the ILA2016 Conference., p. 12 deals with the issue of arbitral tribunal's power to disqualify counsel.

The issues arose are related to the extent of the arbitral tribunal's power to disqualify counsel as special (what kind of?) circumstance only necessary to safeguard the essential integrity and fairness of the arbitral process. Therefore, guidelines became required to develop principles and remedies/ sanctions of tribunals' inherent power to protect proceedings, even in cases when is necessary to identify if the underlying dispute is characterized by bad faith conduct or infected with corruption or to punish contempt of a tribunal's decisions.

The natural basis of the arbitrator's inherent authority to sanction bad faith participation in the arbitration is given by the comprehensive arbitral authority expressly conferred on the arbitrators and the general power of any tribunal to control its own process, a power clearly recognized and established by all arbitration statutes [ILA, 2014]. The power of the arbitral tribunal derives from the traditional authority of a court to judicially supervise the local legal profession, from the need to secure the proper administration of justice, to ensure the police of the proceedings, the discipline for misconduct, along with the need to protect the parties from malpractice attended with fraud and corruption [Rau, 2014]. The parties entrusted to the arbitral tribunal an extensive power to determine the procedural roadmap and the case management of the dispute, as the arbitrators are identified as the real guardians of the due process.

The issue rose in these cases and subsequent ones related to counsel's conduct and party representations matters are now addressed by the IBA Guidelines on Party Representation in International Arbitration adopted by the IBA Council on May 22, 2013, which were presented above. 


\author{
(online) $=$ ISSN $2285-3642$ \\ ISSN-L = 2285-3642 \\ Journal of Economic Development, Environment and People \\ Volume 4, Issue 4, 2015 \\ URL: $\underline{\text { http://jedep.spiruharet.ro }}$ \\ e-mail: office jedep@spiruharet.ro
}

\title{
6.1 Hrvatska Case
}

In Hrvatska case, the ICSID arbitral tribunal based on the concept of inherent powers rendered the decision that a party's chosen counsel could not participate in arbitration proceedings. Although the case did not involve allegations of bad faith or professional misconduct, is considered the first international arbitral tribunal that invoked the supranational standards of counsel's conduct. The circumstances of the case were related to disclosure obligations of relations between the counsel and arbitrator and the possible consequences of counsel's emergence on the composition of the arbitral tribunal [Wilske, 2011].

The excluded counsel's attendance in the case was disclosed only shortly before the merits of the final hearing. That counsel was a member of the same London Chambers at which the tribunal's president was a "door tenant." [Tribunal's Order, 2008, para. 3] The opposing party, who was not familiar with the English legal system's "split profession" of solicitors and barristers, objected that the participation created an "appearance of impropriety." [Tribunal's Order, 2008, para. 7,21]. Also it has claimed that the circumstances of disclosure's tardiness could have been avoided if the respondent had disclosed the relationship at an earlier stage. The respondent's refusal to reveal the scope of Mr. Mildon's involvement when asked by the claimant had further complicated the issue and delayed its resolution.

Counsel for the claimant referred to ICSID Arbitration Rule 18(1) which obliges a party to notify the Secretary General of the identity of counsel; also Rule 19, which states that the "Tribunal shall make the order required for the conduct of the proceeding" and to Rule 39, which states that provisional measures could be made "for the preservation of (a party's) rights". Counsel for the respondent argued that it was not aware of any inherent jurisdiction or authority that would enable the tribunal to grant such relief [Olswang, 2009].

Even if the arbitral tribunal founded that the ICSID Convention does not grant the tribunal any explicit power to exclude counsel and there is a fundamental principle that parties may use the lawyers of their choice, this principle is subject to an overriding principle of the immutability of properly-constituted tribunals, created so as to prevent parties who wished to delay the proceedings from submitting claims that would compel an arbitrator to resign and so cause a tardy re-constitution of the tribunal. This means that a party cannot amend its legal team after the constitution of the tribunal "in such a fashion as to imperil the Tribunal's status or legitimacy", the cardinal principle of the immutability of the arbitration tribunal prevailing.

In determining that counsel's participation would be inappropriate, the tribunal cited its "inherent power to take measures to preserve the integrity of its proceedings." [Tribunal's Order, 2008, para. 33, 34]. It remarked that this power found "a textual foothold" in Article 44 of the ICSID Convention, which grants discretion on procedural issues, and observed that, more broadly, international courts possess an inherent power, independent of statutory reference, "to deal with any issues necessary for the conduct of matters falling within [their] jurisdiction." [Tribunal's Order, 2008, para. 33].

Strongly affected by the very late disclosure of the barrister's role in the case, the Tribunal disqualified the barrister from the case although specified that there is no "hard and fast rule" preventing barristers from the same Chambers from acting as arbitrator and counsel in the same case [Bishop, 2010] ("the lack of 


\author{
(online) $=$ ISSN $2285-3642$ \\ ISSN-L = 2285-3642 \\ Journal of Economic Development, Environment and People \\ Volume 4, Issue 4, 2015 \\ URL: $\underline{\text { http://jedep.spiruharet.ro }}$ \\ e-mail: office jedep@spiruharet.ro
}

clarity as to which ethical rules apply, the existence of conflicting rules and obligations, the nontransparency and the increased size of many proceedings, combined with greater public scrutiny, creates a certain instability in the system that could result in a future crisis of confidence"). Moreover, having learnt that the excluded counsel was held in relation to damages issue only, it bifurcated the proceedings and postponed all damages questions for later determination when substitute counsel could be used by the respondent.

A peculiarity of this case was that the challenge was not to the president continuing on the tribunal; the parties were agreed that the president should not recuse himself. Instead the claimant sought an order that the respondents refrain from using the counsel in question.

\title{
6.2 Rompetrol Case
}

Here the arbitral tribunal noted that its reasoning is not to be considered as a recast of Hrvatska decision, but that "the Hrvatska decision might better be seen as an ad-hoc sanction for the failure to make proper disclosure in good time than as a holding of more general scope" [Whitsitt, 2010; Rompetrol Decision, para 25].

The fact of this case concerns a challenge to the lead counsel for Rompetrol which during the proceedings passed the legal conduct of the case from a particular partner in a law firm which retired from the business with another one which proved to be employed by a firm in which one of the arbitrators was a partner. The respondent challenged the propriety of the new appointed counsel and applied for an order requiring the claimant to remove the counsel from the case and to prohibit its further participation in the proceedings. It is noteworthy that respondent expressly pointed out that it is not looking for an arbitrator challenge.

The tribunal differentiated the circumstances present in Hrvatska and asserted that the decision "might be better seen as an ad hoc sanction for the failure to make proper disclosure in good time than as a holding of more general scope." The tribunal examined also the application of IBA Guidelines on Conflicts of Interest, remarking that they are not binding, and considered the alleged irregularity does not compromise the essential integrity of the process to justify the counsel's exclusion, even observing the tribunals' inherent power to do so. The arbitrators which act in such cases and tribunals possess "high moral character and recognized competence" and are not considered as biased, even in such situation. The tribunal referred to the European Court of Human Rights (Article 6 - the right for a fair trial), where the jurisprudence indicated the objective test for arbitrator bias: "whether a fair-minded and informed observer having considered the facts, would conclude that there was a real possibility that the tribunal was biased".

Accordingly, the tribunal rejected the respondent's request and posed a question mark on the lack of the relevant legal text to expressly provide for such inherent power and commented that "absent express provision, the only justification for the tribunal to award itself the power by extrapolation would be an overriding and undeniable need to safeguard the essential integrity of the entire arbitral process." It postulated that such power would be rarely and only in compelling circumstances employed.

Analyzing the position in more detail, the tribunal noted that there was no requirement for legal representatives to be impartial or unbiased. On the contrary, parties were entitled to freedom of choice in 


\author{
(online) $=$ ISSN $2285-3642$ \\ ISSN-L = 2285-3642 \\ Journal of Economic Development, Environment and People \\ Volume 4, Issue 4, 2015 \\ URL: $\underline{\text { http://jedep.spiruharet.ro }}$ \\ e-mail: office jedep@spiruharet.ro
}

their legal representation. There was no necessary tension between the basic principles of the independence and impartiality of the tribunal on the one hand, and the freedom of representation on the other. In most cases, the tribunal should balance these two principles rather than assigning priority to one over the other.

The tribunal clearly wished to discourage challenges to legal representatives, noting that "to put the matter bluntly, there should be no room for any idea to gain ground that challenging counsel is a handy alternative to raising a challenge against the tribunal itself, with all the consequences that the latter implies". Hrvatska was carefully distinguished and analyzed as a case where the tribunal had imposed an "ad hoc sanction for the failure to make proper disclosure [of the late appointment of the barrister in question]", rather than as a "holding of more general scope".

The award represents a deliberate retreat from the decision in Hrvatska, in which a barrister was excluded from arbitration) and releases a contrary opinion, as a warning that parties should not pursue counsel challenge instead of arbitrator challenge as an alternative, considering that the circumstance of the case do not justify such a disqualification, as the evidence did not establish that there was a "real possibility" of bias and there was, therefore, no basis for the tribunal interfering in the claimant's choice of legal representation.

These cases involve ethical issues concerning the relationship between counsel and one of the arbitrators or cases when the same person fulfil the mission of arbitrator or counsel in different proceedings, but with similar legal matters at stake. Given the increased number of arbitrators and counsels in arbitration nowadays, these issues were about to happen anyway and it is important that certain measures to be taken in order to articulate and regulate such circumstances.

\title{
7. Conclusion
}

These motions for disqualification of unethical counsels appointed at a later stage in arbitral proceedings might be seen as the equivalent or surrogate of the challenge of the arbitrators themselves, but as a less burdensome alternative. The beaten track in cases when conflicts of interest occur between arbitrators and counsels, already standardized in IBA Guidelines on Conflicts of Interest, is to challenge the arbitrator, as the nomination of its own counsel is perceived as a party's right which until now has not been infringed. The disqualification of counsel should rest on the same basis that would justify the disqualification of an arbitrator, as raised the same doubts about the integrity of the decision-making process [Rau, 2014, p. 20]. Consequently is not the counsel sanctioned, but the effect of his conduct on the legitimacy of the tribunal. And for efficiency purpose, when the matter intervened, it is advisable to be taken into account the cost/ benefit analysis given the stage of the proceedings and weighing which challenge will be less disruptive. It seems that the general idea is to find feasible solutions by resourceful arbitrators on case by case approach.

Regarding of the arbitral tribunal to exclude counsel, this can be seen also from another view, as a right to withhold the approval of the new counsel to be appointed. This is a rule used in practice, the institution and the arbitral tribunal request to be informed during the proceedings of any change in the teams of the counsels representing parties. But once appointed, the counsel which fail to disclose in due time potential conflicts of interest with other colleagues or arbitrators nominated is sanctioned with its exclusion. The 


\author{
(online) $=$ ISSN $2285-3642$ \\ ISSN-L = 2285 - 3642 \\ Journal of Economic Development, Environment and People \\ Volume 4, Issue 4, 2015 \\ URL: http://jedep.spiruharet.ro \\ e-mail: office jedep@spiruharet.ro
}

counsel can use the late appointment as a tactical behavior recognized as a guerrilla tactic and could blur the arbitral tribunal's conscious or unconscious ability to judge fairly further in the process.

The basic source of the arbitral tribunal disqualifying counsel is to be found in the scope of the consent of the parties. This submission could be express or implicit, when parties voluntarily adopted the institutional rules. The parties entrusted the arbitral tribunal with a wide-ranging authority to determine how to proceed to settle the dispute. Nevertheless, the arbitral tribunal is compel to ensure the due process, an efficient conduct preserving the fundamental integrity, effectiveness and fairness of the arbitral proceedings, all of these under the parties' legitimate expectations aligned to respectable standards in the field.

It is then the arbitral institutions' mission to ensure sufficient codification addressing all potential issue related to ethics in international arbitration. Too much regulation is neither desirable nor advisable, but from practice and the fact that arbitration has become a big business (especially for the lawyers) lately emerged the necessity to increase the measure against the guerrilla tactics endangering the integrity and fairness of the arbitral proceedings and thus to ensure the public demands for transparency.

Ethical practices and transparency in the world of international arbitration persistently evolve, and there are raising constantly fresh trends and new-born issues to tackle. That it is why one should keep an open minded to the entire regulation/ codification and new situations arising from practice in order to find best solutions to the ethical issue, topic which will continuously develop and for which ingenious interpretations and clarifications are indispensable.

\title{
8. References
}

[1] Bishop, D. (2010) Ethics in International Arbitration, ICCA 20 ${ }^{\text {th }}$ Congress Rio de Janeiro. Available at http://www.arbitration-icca.org/media/0/12763302233510/icca rio keynote speech.pdf.

[2] Born, G. (2009) International Commercial Arbitration, Alphen aan den Rijn: Wolters Kluwer, p. $2879,2880$.

[3] Brower, C.N. (2010) The Ethics of Arbitration, Berkeley Journal International Law Publicist vol. 5, p. 8. Available at http://bjil.typepad.com/brower final.pdf.

[4] Fernández Rozas, J.C. (2010) Clearer Ethics Guidelines and Comparative Standards for Arbitrators, Liber Amicorum Bernardo Cremades, Madrid: La Ley, p. 413-449. Available at http://eprints.ucm.es/11931/1/CLEARER ETHICS GUIDELINES FOR ARBITRATORS.pdf.

[5] Horvath, G; Wilske, S. (2013) Guerrilla Tactics in International Arbitration, Alphen aan den Rijn: Wolters Kluwer.

[6] Hunter, M.; Paulsson, J. (1985) A Code of Ethics for Arbitrators in International Commercial Arbitration, Arbitration International vol. 13, p. 153.

[7] Olswang, Arbitration Tribunal Upholds Principle of the Immutability of Tribunals. Available at http://www.olswang.com/articles/2009/02/arbitration-tribunal-upholds-principle-of-the-immutability-oftribunals/ 24 February 2009. 


\author{
(online) $=$ ISSN $2285-3642$ \\ ISSN-L = 2285 - 3642 \\ Journal of Economic Development, Environment and People \\ Volume 4, Issue 4, 2015 \\ URL: http://jedep.spiruharet.ro \\ e-mail: office jedep@spiruharet.ro
}

[8] Park W.W. (2009) Arbitrator Integrity: The Transient and the Permanent, San Diego Law Review vol. 46, p. 629, 635.

[9] Paulsson, J. (1992) Standards of Conduct for Counsel in International Arbitration, American Review of International Arbitration vol. 3, p. 214, 215.

[10] Peters, P. (2010) Can I do this? - Arbitrator's Ethics, Available at http://kluwerarbitrationblog.com/blog/2010/11/09/can-i-do-this-\%E2\%80\%93-arbitrator\%E2\%80\%99s-ethics/.

[11] Rau, A. S. (2014)2014-01. Available at http://ssrn.com/abstract=2403054.

[12] Rogers, C. (2014), Ethics in International Arbitration, Oxford and New York: Oxford University Press.

[13] Rogers, C; Jeng, J. (2014), The Ethics of International Arbitrators, The Leading Arbitrators' Guide to International Arbitration, Third edition, New York: Juris, p. 175-206.

[14] Sands, P. QC (2011) Conflict and Conflicts in Investment Treaty Arbitration: Ethical Standards for Counsel, Evolution in Investment Treaty Law and Arbitration, Cambridge: Cambridge University Press, p. 21, 22. Available at https://books.google.ro/books?id=wboa4 uTTD8C\&printsec=frontcover\#v=onepage\&q\&f=false.

[15] Whitsitt, E. (2010) ICSID Tribunals Affirms Power to Exclude Counsel, But Declines to Do So, Investment Treaty News 6. Available at https://www.iisd.org/itn/2010/02/10/icsid-tribunal-affirms-power-to-exclude-counsel-butdeclines-to-do-so-2/.

[16] Wilske, S. (2011) Arbitration Guerrillas at the Gate, Austrian Yearbook on International Arbitration 2011, Wien: Manz, p. 325.

[17] Ziadé, N.G. (2015) How Should Arbitral Institutions Address Issues of Conflicts of Interest? Festschrift Ahmed Sadek El-Kosheri, Alphen aan den Rijn: Wolters Kluwer. 